DOI: https://doi.org/10.36477/tourismhospcee-1-2

UDC 338.486.2:330.341

\author{
Biletska Iryna \\ Ivano-Frankivsk Educational and Scientific Institute of \\ Ternopil National Economic University \\ ORCID: https://orcid.org/0000-0002-6906-7161
}

Білецька I. М.

доктор економічних наук, доцент, завідувач кафедри міжнародної економіки, маркетингу і менеджменту

Івано-Франківського навчально-наукового інституту менеджменту

Тернопільського національного економічного університету

\title{
SUBSTANTIATION OF ELEMENTS AND STRUCTURE OF ORGANIZATIONAL AND ECONOMIC MECHANISM OF INTERNET MARKETING FOR DEVELOPING TOURISM ENTERPRISES ON INNOVATIVE PRINCIPLES
}

\author{
ОБГРУНТУВАННЯ ЕЛЕМЕНТІВ І СТРУКТУРИ ОРГАНІЗАЦЙНО- \\ ЕКОНОМІЧНОГО МЕХАНІЗМУ ІНТЕРНЕТ-МАРКЕТИНГУ РОЗВИТКУ \\ ПІДПРИЄМСТВ ТУРИЗМУ НА ІННОВАЦИЙИХ ЗАСАДАХ
}

Perspective directions in strategizing the Internet marketing policy for innovative development of tourism enterprises are formed. A methodological approach has been developed and proposed, which allows to effectively and on an institutional basis combine opposite strategic vectors of activating Internet marketing of innovation: external vector (when a company focuses on innovation, related to trends in market demand and external need for innovation) and internal vector (when the path of innovative development and activity is determined by internal potential and financial resource capacity). Thus, the peculiarity of the author's approach is in the identification of organizational-managerial, information-technological, integrated, financial-investment, marketing, immanent, infrastructural, cluster and interactive spatial-network directions of innovative development with clear signs of synergy. The applied significance of the research is to determine the strategic concept and design a structure of the organizational and economic mechanism for improving Internet marketing of tourism enterprises on an innovative basis, as well as to substantiate the provisions of the organizational and economic mechanism of tourism development on an innovative basis. The scientific novelty of the research results is that the developed tools of policy of formation and implementation of organizational and economic mechanism of Internet marketing for the tourism enterprise development on innovative principles based on new tools and concepts of system and complexity of their combination, traditional substantiation of a set of proposals for the organization and control of innovation, the introduction of a number of economic incentives and motives for its internal and external actors. Such innovative principles allowed to substantiate the essential-typological and applied characteristics of functional and structural elements of the organizational-economic mechanism: institutional-legal base, administrative-functional apparatus, information-analytical block, scientific-technical support, financial-investment support, market-interface superstructure, intellectual-personnel component and logistics.

Keywords: tourism enterprises, Internet marketing, organizational and economic mechanism, innovative development, strategy.

Сформовані перспективні напрями стратегування політики інтернет-маркетингу інноваційного розвитку підприємств туризму. Розроблено $і$ запропоновано методичний підхід, який дозволяє ефективно та на інституційній основі поєднати протилежні за характером стратегічні вектори активізації інтернетмаркетингу інновачійної діяльності: зовнішній (коли підприємство орієнтується на інновації, пов'язані з тенденціями зміни ринкового попиту і зовнішнього «запиту» інновацій) та внутрішній (коли шлях інноваційного розвитку і активності визначається внутрішнім потенціалом та фінансово-ресурсним забезпеченням); відтак, особливість авторського підходу - в ідентифікації організаційно-управлінського, інформаційно-технологічного, інтегрованого, фінансово-інвестиційного, маркетингового, іманентного, інфраструктурного, кластерного та інтерактивного просторово-мережевого напрямів інноваційного розвитку з чітко вираженими ознаками синергізму.

Ключові слова: підприємства туризму, інтернет-маркетинг, організаційно-економічний механізм, інноваційний розвиток, стратегія.

Сформированы перспективные направления стратегирование политики интернет-маркетинга инновационного развития предприятий туризма. Разработан и предложен методический подход, который позволяет эффективно и на институциональной основе совместить противоположные по характеру стра- 
тегические векторы активизации интернет-маркетинга инновационной деятельности: внешний (когда предприятие ориентируется на инновации, связанные с тенденциями изменения рыночного спроса и внешнего «запроса» инноваций) и внутренний (когда путь инновационного развития и активности определяется внутренним потенциалом и финансово-ресурсным обеспечением); следовательно, особенность авторского подхода - в идентификации организационно-управленческого, информационно-технологического, интегрированного, финансово-инвестиционного, маркетингового, имманентного, инфраструктурного, кластерного и интерактивного пространственно-сетевого направлений инновационного развития с четко выраженными признаками синергизма.

Ключевые слова: предприятия туризма, интернет-маркетинг, организаџионно-экономический механизм, инновационное развитие, стратегия.

Statement of the problem. Ukraine has unique and diverse natural and climate conditions and resources, historical and cultural heritage, folk traditions, a network of recreational and sanatorium facilities, which form a significant potential for tourism in general and tourism enterprises in particular. However, the available opportunities are not realized, and domestic tourism enterprises do not fully perform their inherent socio-economic functions and tasks, yielding to the key parameters of the volume and efficiency of tourism businesses in countries with a high level of tourism development. These are the share in GDP, employment and tax payments, the number of tourists served, income per capita and per employee, the level of capitalization of enterprises and investment, the state of modernization of material, technical and technological base of tourist facilities.

Today, the world wide web is becoming more widespread. It penetrates into all parts of human life: work via the Internet, learning via the Internet, communication, online games and more. In recent years, the Internet has penetrated the economy, which has given rise to the concept of "Internet marketing".

The Internet takes businesses to the global level, simplifies and improves the conclusion of various agreements between companies, speeds up communication and helps find the target audience, as well as the distribution of their products and/or services via the Internet. We can say that the Internet is becoming increasingly important not only for the main Internet users but even for the economic development of various enterprises and countries.

The current conditions of functioning and development of tourism enterprises in Ukraine is determined by a set of causes and factors of both internal and external nature. Their further stable development is largely accompanied with the difficulties of counteracting the intensification of competition in the market of tourist services in the context of globalization, digitalization, simplification of border crossings, growth of tourist activity and diversification of national tourist products.

Such circumstances increasingly raise the issue of substantiation of theoretical and methodological provisions and applied recommendations for the development and implementation of new modern and effective mechanisms and tools for Internet marketing of innovative management of tourist enterprises.
Analysis of recent research and publications. The general conditions and principles of innovation and technological activities of both tourist enterprises and the domestic tourist industry are studied in depth by T. Vasyltsiv, A. Shekhlovych [1], Y. Migushchenko [2], I. Orlyk [3], O. Vlasyuk [4], R. Lupak [5], A. Golod [6], O. Melnychenko [7], A. Okhrimenko [8], A. Dymchuk [9] and others.

Selection of previously unsolved parts of the overall problem. Today we are characterized by new trends, factors and conditions of functioning and development of tourism enterprises due to globalization processes, as well as the introduction of Internet marketing tools. They are insufficiently studied and new approaches to development are required.

Setting objectives. The purpose of the article is to substantiate the elements and structure of the organizational and economic mechanism of Internet marketing for developing tourism enterprises on an innovative basis.

Presentation of the main material of the study. Development of tourist enterprises with the use of Internet marketing tools on an innovative basis requires constructing an adequate resource and management support, which provides not only taking into account the specifics of the tourism industry but also the ability to identify and mobilize unused reserves of innovative modernization of these enterprises, and conditions of market and economic environment. The most effective and rational option for the organizing such a support is the formation of an appropriate organizational and economic mechanism for the development of tourism enterprises on an innovative basis. Adherence to this approach, on the one hand, will ensure the maximization of the manageability of the development of tourism enterprises, and on the other hand, will minimize risks in the context of structural adjustment and innovative modernization of these enterprises.

The expediency of substantiation of the organizational and economic mechanism for development of tourism enterprises on innovative principles is strengthened in view of the following: 1) globalization of the tourist service market, which demands accurate structuring of strategic purposes, resource opportunities and applied tools for functioning of tourism enterprises; 2) the rapid pace of development of scientific and technological progress, in which 
existing technologies undergo structural changes in a short term, and knowledge has a high ability to "age"; 3) imbalance of managerial influences regarding the coordination of the processes of development of tourist enterprises at the macro-, meso- and micro-levels, which requires coordination and settlement; 4) imperfection of the institutional environment of tourism enterprises characterized by an excessive number of institutional barriers, contradictions and pitfalls, as well as the imbalance of the impact of formal and informal institutions on management decision-making in the field of tourism; 5) the growing European integration challenges for the development of tourism enterprises, which requires not only harmonization of domestic and European requirements for the functioning of the tourist industry, but also raising the level of quality standards for customer service; 6 ) the dynamic nature of the development of the tourism industry and the strengthening of the competitive environment in both domestic and foreign tourism market; 7) the prevailing wear and resource constraints of the material and technical base of domestic tourism enterprises; 8) the lack of a comprehensive state policy for innovative development of enterprises in the tourism industry.

Substantiation of the elements and structure of the organizational and economic mechanism for development of tourist enterprises on an innovative basis requires clarification of its essential and substantive characteristics. The interdisciplinary concept of "mechanism" is positioned as a holistic set of internal components that function with each other based on established relationships and regulations in order to achieve goals and objectives.

On the one hand, the mechanism is an autonomous tool for regulating socio-economic development at any of the hierarchical levels of management of the national economy, and on the other - its structure and functional parameters must be endowed with high adaptive properties due to the need for constant interaction with internal factors and external nature in the uncertainty of the environment of socio-economic systems.

Ensuring the adequacy and functionality of the organizational and economic mechanism of innovative development should provide for compliance of its project structure with modern challenges, goals and capabilities of tourism enterprises, which create preconditions for rapid response and counteraction to destabilizing threats, for guaranteeing resource support for extended reproduction of tourism enterprises, for ensuring sustainable functioning of organizational and economic mechanism for innovative development under conditions of system transformations and market shocks.

The strategic conceptual and project structure of the organizational and economic mechanism for innovative development of tourism enterprises is pre- sented in Figure 1. Substantiation of elements and structural components of the organizational and economic mechanism for development of tourist enterprises on an innovative basis requires consideration of the following features: 1) strategic focus of innovative modernization of tourism enterprises on the priority interests, needs, preferences and tastes of potential customers; 2) ensuring the integration nature of the projected mechanism, since the introduction of innovations requires mobilizing and balancing the resource management processes not only in the tourism sector, but also in banking and finance, science and technology, infrastructure and logistics, etc.; 3 ) coordination of parameters and functional-sectoral structure of projected innovations in tourism with opportunities and needs of potential effective demand in the market; 4) organizational and economic mechanism for innovative development of enterprises should provide for existing spatial and territorial specifics of the geographical location of the objects' network in the tourism industry and its regional specialization; 5) the designed organizational and economic mechanism should have a diversified set of tools to intensify the innovative activities of enterprises, given the high specialization of the tourism industry and a wide range of tourism services; 6) large-scale globalization and digitalization of the market of tourist services under total informatization of social and economic relations; 7) the organizational and economic mechanism should provide clear opportunities and ways to harmonize domestic standards for tourist service delivery with advanced international norms and requirements in the short term; 8) the designed mechanism must be resource-capable and timely implement preventive measures to prevent blocking and disrupting the process of innovative modernization of the tourist enterprise; 9) the organizational and economic mechanism should provide clear sources of financing and distribution of funds between the participants of the innovation process of the tourist enterprise; 10) innovative modernization of tourist enterprises should take place in the context of compliance with the basic principles of sustainable development of the state.

It is obvious that the mechanism for development of tourist enterprises on an innovative basis constitutes of organizational and economic components. The functioning of the first one is aimed at forming organizational and managerial structures to regulate the processes of innovative modernization of tourism enterprises, distribution of powers and responsibilities during the implementation of the innovation project, balancing strategic and tactical goals in the field of innovation with the available resource potential of tourism enterprises. In turn, the functioning of the economic component is aimed at creating a favourable environment and conditions for the implementation of innovative projects, which, on the one hand, 


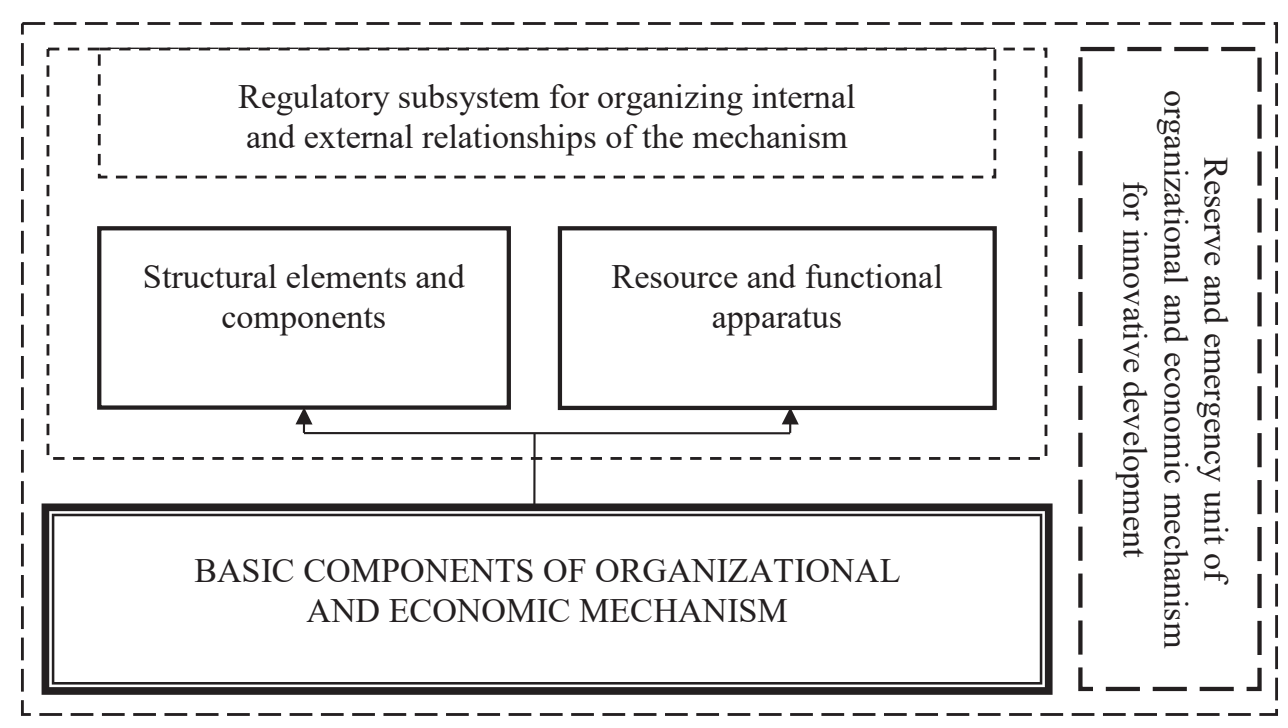

Figure 1. Strategic conceptual and project structure of the organizational and economic mechanism for development of tourist enterprises on an innovative basis with the use of Internet marketing

ensures an adequate level of resource support, and on the other - the establishment of effective communication relationships with innovation actors in terms of internal and external environment of the tourist enterprise.

The fundamental structural element of the organizational component of the mechanism for development of tourist enterprises on an innovative basis is the institutional and legal framework, which is designed to provide regular support for the processes of innovative modernization. It is expedient to aggregate the institutional and legal basis from internal and external superstructures. The internal superstructure determines the institutional parameters and principles of implementation of innovative changes in terms of business processes of the tourism enterprise, while the functioning of the external one aims at establishing general rules of the game for innovation in order to ensure a healthy competitive environment. To formalize the effective institutional and legal basis of the organizational and economic mechanism for development of tourism enterprises on an innovative basis, it is advisable to implement the following measures: 1) bring the regulatory framework for innovation in line with the requirements and needs of tourism enterprises based on favourable conditions for investment in the sphere of tourism, anticipation of opportunities to establish preferential tax regimes for the introduction of certain types of investments, institutional ensuring of technical and technological support for implementation of the innovation process of tourism enterprises; 2) eliminate institutional barriers and institutional traps of innovative development of tourism enterprises by eliminating legislative gaps, overcoming the existing imbalances between the formal and informal institutions in the implemen- tation of innovations, minimizing irrational subjective influences on management decisions in the field of innovative development of tourism enterprises; 3 ) form an institutional basis for intensifying the processes of project-innovation cooperation between tourism enterprises, scientific and technical entities, investment and financial institutions to provide the integration of resources and the formation of clear mechanisms for dividing spheres of influence in the implementation of innovative projects.

Activating the processes of innovative development of tourist enterprises requires the adoption of effective management decisions of strategic and tactical-operational nature in the uncertain economic environment of these enterprises. In this regard, it is advisable to build an objective information base for management decisions, which can quickly, timely and accurately keep the subjects of the management of the designed mechanism informed to provide control of the processes of innovative modernization of tourism enterprises. Formalization of the information-analytical block of the mechanism for development of the enterprises of tourism on innovative bases demands realization of such measures:

- organization of systematic monitoring and collection of information data in the field of innovative development of tourism enterprises using periodic marketing research among customers, contractors and key competitors in the market, establishing information dialogue with scientific and technical institutions and innovation centers, monitoring the implementation of tourism innovations in the market, diversification of sources of information and verification of its quantitative and qualitative content;

- ensuring a systematization of collected data based on automation of the input information processing, 
organization of its reliability and objectivity verification, filtering of redundant information, formation of a limited range of user access to the data, prevention of leakage of information containing trade secrets (including the structure and technology of the innovation project), presentation of the information in the form accessible to the end user, provision of reliable protection and safe storage of the collected information;

- organization of the process of objective analysis of systematized information through a set of established relationships and interdependencies in innovation process development, identification of significant determinants activating innovation modernization of tourism enterprises, identification of system components of innovation projects, modelling risks and threats of priority innovations, level of innovation capitalization.

The strategic core of the organizational and economic mechanism for development of tourist enterprises on an innovative basis is its scientific and technological support, which not only identifies the parameters of efficiency of the target innovation project, but also determines the technical and technological possibilities of innovation, forms intellectual and personnel potential of innovative modernization, determines the prospects for capitalization of implemented innovations.

The formation of adequate scientific and technological support for innovative development of tourism enterprises requires focus on achieving the following strategic priorities: 1) intensification of design and innovation activities, which is the prerogative of medium and large tourism enterprises, by creating design and innovation units, financing design and innovation activities; procurement of innovative technologies, involvement of scientific personnel in the process of innovation development, reorientation of resource provision in the segment of scientific and technological search; 2) stimulating the development of cooperation of tourist enterprises with research and innovation centers (research institutions, higher education institutions, venture companies, science and technology parks, etc.) based on implementing the practice of joint innovation projects, forming a scientific and practical base for training and retraining of intellectuals, joint conferences, seminars and round tables, creation of integration research and innovation clusters, dissemination of the practice of exchanging experience in the development and implementation of innovations; 3) development of outsourcing of scientific and technical support for innovative activities of tourism enterprises through delegating the project-innovative activity to specialized companies providing scientific and technological support for innovation development of tourist enterprises on the basis of contractual lease.

The resource basis for intensifying the processes of innovative development of tourism enterprises is the formation of their adequate financial and investment support, which is an integral structural element of the economic component of the designed mechanism. The resource capacity of this support determines the strategic scale and parameters of the implementation of innovative changes in the business processes of tourism enterprises. Ensuring appropriate financial and investment support is important not only at the design stage of innovations, but also in the process of their testing, implementation and market capitalization. The formation of adequate financial and investment support for innovation development is complicated by both the objective (resource constraints of tourism enterprises, insufficient liquidity of the banking and financial sector, underdeveloped network of investment infrastructure, high risks of innovation projects) and subjective factors (unformed incentives and fears from the heads of tourism enterprises regarding the implementation of investments in the innovation sphere, the presence of structural changes, which are accompanied by processes of innovative modernization and carry the risks of losing established relationships and interests for employees, the predominance of the role of short-term financial goals and motives over the strategic priorities of a tourism enterprise). Providing financial and investment support for the development of tourism enterprises on an innovative basis requires the implementation of the following measures:

- restructuring of existing approaches to budgeting of tourist enterprises, which provides for directing own funds to finance the development of innovations, establishing the practice of reinvesting the share of profits in the field of innovation, mobilization of unused reserve funds to fill the budget of enterprises to further redistribute them to support the implementation of innovative projects, levelling the budget expenditures and revenue of tourism enterprises through the capitalization of implemented innovations, optimization of the ratio of own and borrowed funds for the needs of innovation;

- diversification of sources of financial resources for the implementation of innovative projects based on intensification of cooperation with the banking and financial sector, the network of infrastructure of investment and innovative development, strengthening the participation of enterprises in leasing and venture financing projects, attracting grants (including funds of the European Union), organization of the functioning of technology parks, lobbying for the creation of scientific and technical clusters;

- dissemination of practice of insurance for innovative activities of tourist enterprises by implementing mechanisms of partial state guarantee of realization of innovative projects, establishing and developing the cooperation with insurance companies, minimizing the risks of failure of innovative projects realization and increasing the level of capitalization of introduced innovations. 
An important aspect in the process of forming the organizational and economic mechanism for development of tourism enterprises on an innovative basis is the design of its market-interface superstructure, which, on the one hand, allows organizing effective interaction of enterprises with their counterparts, and on the other - to model priority areas of innovation in tourism industry. This can be achieved by cooperating with the subjects of the tourism market establishing the practice of periodic joint exchange of innovative experiences, minimizing the risks of innovation in the market. The formation of market-interface superstructure of organizational and economic mechanism for innovative development of tourism enterprises involves the implementation of the following meas- ures: 1) construction of communication tools with clients by providing strategic orientation on satisfaction of their perspective inquiries and requirements, forecasting of parameters of development of innovations in the tourist market, by setting bilateral relationship between the company and the client in order to predict the parameters of the development of its innovative needs, as well as expanding the traditional range of satisfaction of its interests; 2) organization of bilateral relations with business partners based on joint innovation exhibitions, fairs, conferences, intensification of informal integration associations in the innovation sphere, organization of joint exchange of innovation experience in order to avoid traditional risks in the implementation of investment and inno-

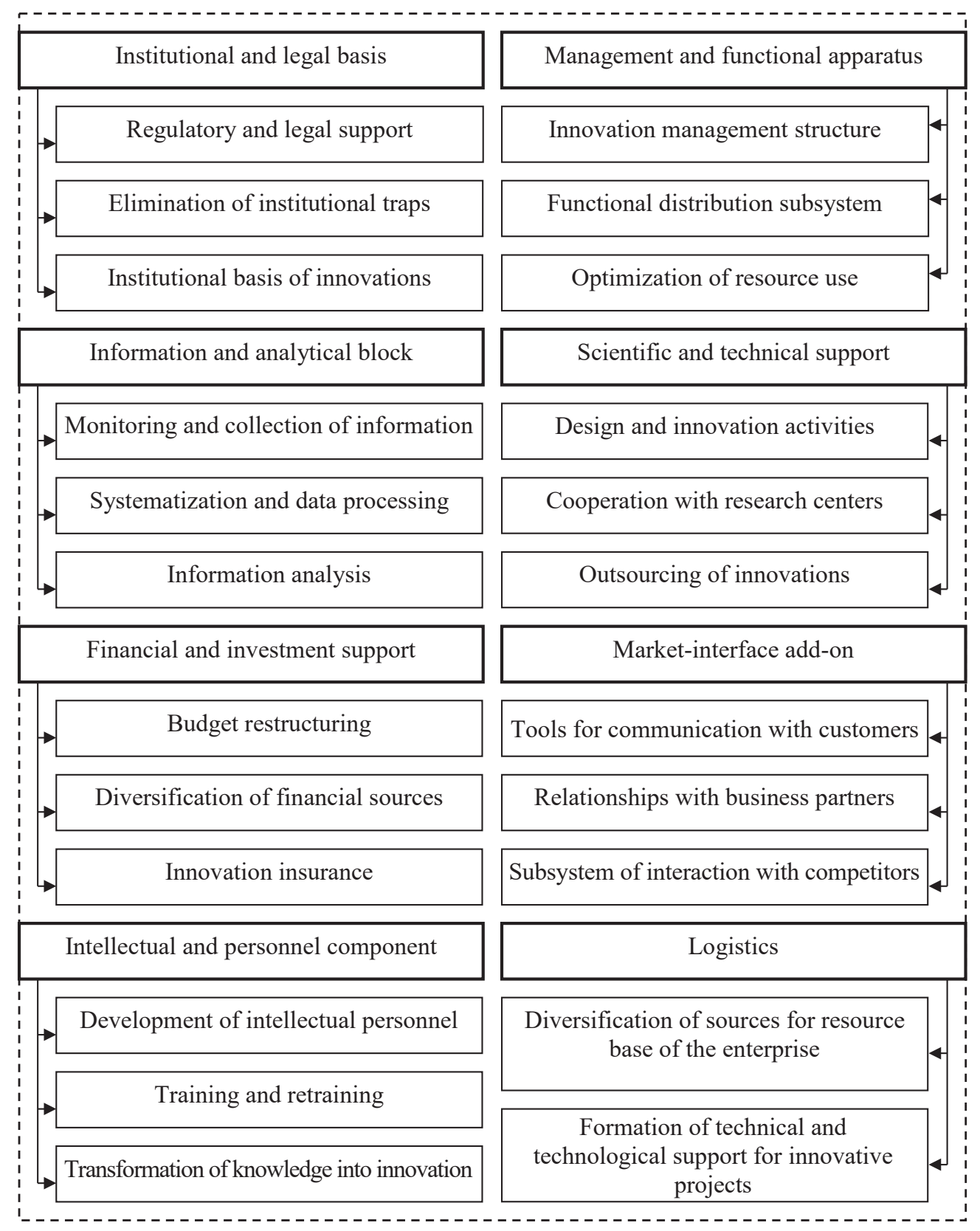

Figure 2. Organizational and economic mechanism for development of a tourist enterprise on an innovative basis with the use of Internet marketing 
vation projects, combining the resource capabilities in innovation development and implementation; 3) building a subsystem of interaction with competitors by organizing intelligence activities in the field of innovation, organizing opportunities for adaptive implementation of innovations of competitors in the tourism enterprise, counteracting unauthorized leakage of innovative information outside the enterprise, optimizing the distribution of spheres of influence in target niche segments of the tourism market.

System aggregation of substantiated structural components and elements of the organizational and economic mechanism for development of tourist enterprises on an innovative basis is presented in Figure 2.

Ensuring the effective work of the organizational and economic mechanism for development of tourism enterprises on an innovative basis requires the formation of appropriate conditions for the functioning of the tourism industry, both at the macro and meso levels of management of the national economy. The state policy of support for innovation implementation in tourism enterprises should be aimed at achieving such strategic priorities as the formation of fair and transparent mechanisms for allocating budget funds in tourism, ensuring compliance with the basic principles of fair competition in the tourism market, improving the image of domestic tourism in the world market of tourist services, financing and support for the development of innovative projects, implementation of preventive measures to minimize the risks of raider attacks in the field of tourism. In turn, the strategic priorities for ensuring the effectiveness of the organizational and economic mechanism for innovative development of tourism enterprises at the regional level should be the following: development of innovative infrastructure of the tourism industry, dissemination of practice and organization of innovation fairs in the regions, coordination of regional tourism development programs with avail- able resources and goals at the macro level, establishment of regional and sectoral communications between the subjects of innovative modernization of tourism enterprises.

Thus, the organizational and economic mechanism for innovative development of tourism enterprises is a strategically important regulator of the organization and establishment of effective relationships between the subjects of innovative modernization, a tool to minimize risks of unprofitable innovative projects, a means of increasing the capitalization of innovative products, an apparatus for structuring the interests of participants in socio-economic exchange in the process of innovative transformation of tourism enterprises, which justifies the feasibility of further development of tools for supporting effective functioning of this mechanism.

Conclusions. It is determined that the implementation of strategic priorities and tasks of the policy for innovative development of tourism enterprises requires the creation of a real practical basis for this, based on which the relevant tools and management measures will be consolidated into a single system. This highlights the role and objective need to form, on the one hand, internal and, on the other - external mechanisms for innovative development. Regarding the first one, it is expedient to test the organizational and economic mechanism with key tasks of formation of internal organizational and administrative system of coordination of innovative activity and introduction of a number of necessary economic incentives and motives for its activization and development. The basic blocks of the organizational and economic mechanism are: institutional and legal framework, management and functional apparatus, information and analytical unit, scientific and technical support, financial and investment support, market-interface superstructure, intellectual and personnel component and logistics of innovative development.

\section{References:}

1. Vasyltsiv T. G., Shehlovych A. M., Vasyltsiv V. V. (2017) Finansovo-ekonomichni instrument stymuliuvannia rozvytku IT-sphery Ukrainy [Financial and economic instruments of stimulation of development of IT-sphere of Ukraine]. Economic discourse, no. 4, pp. 128-136.

2. Mihushchenko Yu. V. (2017) Mehanizmy rozvytku turystychnoi galuzi v umovah tymchasovoi okupaciyi terytoriyi Ukrainy: regionalnyi aspekt [Mechanisms of the development of the tourism industry in conditions of temporary occupation of part of the territory of Ukraine: the regional aspect]. Available at: http://lv.niss.gov.ua/public/File/1/AZ_Mihushchenko_2016.pdf (accessed 10 May 2021).

3. Orlyk I. O., Vasyltsiv T. G., Rudyk S. A. (2016) Mehanizmy ta zasoby aktyvizaciyi innovaciynogo rozvytku pidpryemstv rozdribnoyi torgivli [Mechanisms and means of intensification of the innovative development of enterprises of retail trade]. Bulletin of Khmelnytsky National University. Economic sciences, no. 1, pp. 102-109.

4. Vlasiuk O. (2018) System transformations of the national economy: challenges and expectations. University of Economy Publishing House, Bydgoszcz, Poland.

5. Lupak R. L. (2016). Otsinyuvannia formuvannia konkurentnyh perevag turystychnyh pidpryemstv [Assessment of formation of competitive advantages of tourist enterprises]. Bulletin of the Khmelnytsky National University, vol. 3, pp. 189-194.

6. Holod A. (2017) Bezpeka rehionalnykh turystychnykh system: teoriya, metodolohiya ta problemy harantuvannya [Security of Regional Tourist Systems: Theory, Methodology and Guarantee Problems]. Lviv: LDUFK.

7. Melnychenko O. A., Shvedun V. O. (2017) Osoblyvosti rozvytku industriyi turyzmu v Ukrayini [Features of the development of the tourism industry in Ukraine]. Kharkiv: NUTSZU. 
8. Okhrimenko A. H. (2011) Problemy konkyrentospromozhnosti turystychnoyi galuzi Ukrainy [Problems of Competitiveness of the Tourist Industry of Ukraine]. Investytsiyi: praktyka ta dosvid, vol. 5, pp. 42-47.

9. Dymchuk A. V. (2010) Formuvannia turystychnoyi polityky derzhavy v umovah dynamichnyh zmin rynkovogo seredovyshcha [Formation of the tourist policy of the state in conditions of dynamic changes in the market environment]. Ekonomika ta derzhava, vol. 12, pp. 44-45.

\section{Список використаних джерел:}

1. Васильців Т. Г., Шехлович А. М., Васильців В. В. Фінансово-економічні інструменти стимулювання розвитку IT-сфери України. Економічний дискурс. 2017. № 4. С. 128-136.

2. Мігущенко Ю. В. Механізми розвитку туристичної галузі в умовах тимчасової окупації частини території України: регіональний аспект : аналіт. записка. URL: http://lv.niss.gov.ua/public/File/1/AZ_Mihushchenko_2016.pdf

3. Орлик І. О., Васильців Т. Г., Рудик С. А. Механізми та засоби активізації інноваційного розвитку підприємств роздрібної торгівлі. Вісник Хмельницького національного університету. Економічні науки. 2016. № 1. С. $102-109$.

4. System transformations of the national economy: challenges and expectations : collective monograph / edited by O. Vlasiuk and other. Bydgoszcz, Poland : University of Economy Publishing House, 2016. Vol. 1. 357 p.

5. Лупак Р. Л. Оцінювання формування конкурентних переваг туристичних підприємств. Вісник Хмельницького національного університету. 2016. № 3. С. 189-194.

6. Голод А. Безпека регіональних туристичних систем: теорія, методологія та проблеми гарантування : монографія. Львів : ЛДУФК, 2017. 340 с.

7. Мельниченко О. А., Шведун В. О. Особливості розвитку індустрії туризму в Україні : монографія. Харків : Вид-во НУЦЗУ, 2017. 153 с.

8. Охріменко А. Г. Проблеми конкурентоспроможності туристичної галузі України. Інвестиції: практика та досвід. 2011. № 5. С. 42-47.

9. Димчук А. В. Формування туристичної політики держави в умовах динамічних змін ринкового середовища. Економіка та держава. 2010. № 12. С. 44-45. 